\title{
Trinexapac-ethyl Application Regimens Influence Creeping Bentgrass Putting Green Performance
}

\author{
Patrick E. McCullough \\ Department of Plant Biology and Pathology, Rutgers, The State University of \\ New Jersey, New Brunswick, NJ 08901-8520
}

\author{
Haibo Liu ${ }^{2}$ and Lambert B. McCarty ${ }^{3}$ \\ Department of Horticulture, Clemson University, Clemson, SC 29634-0375
}

Additional index words. ball roll, gibberellic acid, GA, plant growth regulator,PGR, stimpmeter

\begin{abstract}
Trinexapac-ethyl (TE) is a plant growth regulator registered for periodic applications on creeping bentgrass greens but ball roll as affected by various TE regimens have not been reported. Field experiments were conducted in Clemson, S.C., from May to July 2003 and 2004 on an 'L-93' creeping bentgrass putting green. Turf received a total of $0.2 \mathrm{~kg} \cdot h \mathrm{a}^{-1}$ a.i. of TE over 12 weeks in three application regimens: $0.017 \mathrm{~kg} \cdot \mathrm{ha}^{-1}$ per week, $0.033 \mathrm{~kg} \cdot \mathrm{ha}^{-1}$ per 2 weeks, and $0.05 \mathrm{~kg} \cdot \mathrm{ha}^{-1}$ per 3 weeks plus a control. Ball roll distances were measured weekly with a stimpmeter in the morning (900 to $1100 \mathrm{HR}$ ) and evening $(>1700 \mathrm{HR})$. Morning ball roll distances were generally longer than evening. Ball roll distances increased from June to July 2003 and from May to July 2004, likely resulting from greater bentgrass summer heat stress during the test period. Turf treated with biweekly and triweekly $T E$ regimens had enhanced ball roll on three and four dates, respectively, but inconsistencies occurred likely from reduced efficacy with greater time between repeated applications. Weekly TE applications enhanced ball roll distances from the untreated by $5 \%$ to $8 \%$ on six dates. Turf injury did not occur following TE applications regardless of regimen. Overall, weekly TE applications increased ball roll distances more frequently than biweekly and triweekly regimens, but enhancements were inconsistent over the 2 years. Chemical name used: [4-(cyclopropyl- $[\alpha]$-hydroxymethylene)-3,5-dioxo-cyclohexane carboxylic acid ethyl ester] (trinexapac-ethyl); (tetrachloroisophthalonitrile) (chlorothalonil); [methyl(E)-2-(2-(6-(2-cyanophenoxy) pyrimidin-4-yloxy)phenyl)-3-methoxyacrylate] (azoxystrobin); [aluminum tris(0-ethyl phosphonate)] (fosetyl-al); [N-(2,6-Dimethylphenyl)-N-(methoxyacetyl) alanine methyl ester] (metalaxyl); [(1-[[2-(2,4-dichlorophenyl)-4propyl-1,3-dioxolan-2-yl) -methyl]-14-1,2,4-triazole] (propiconazole).
\end{abstract}

Plant growth regulator (PGR) applications have become an important practice in creeping bentgrass (Agrostis palustris Huds.) putting green management. Inhibiting bentgrass leaf growth fluctuations with PGRs promotes surface uniformity that further enhances putting green quality (McCarty, 2005). Plant growth regulators that inhibit gibberellic acid (GA) are more frequently used on bentgrass greens than cell division inhibitors because of less likelihood for leaf burn and turfgrass injury (Murphy et al., 2005).

Trinexapac-ethyl (TE) is a GA inhibitor widely used to inhibit leaf growth on bentgrass golf greens. Suppressing shoot growth with TE may enhance creeping bentgrass quality and has shown not to reduce rooting of creeping bentgrass golf greens (Fagerness and Yelverton, 2001; Goss et al., 2002; McCullough et al., 2005a). Turf managers have incorporated $\mathrm{TE}$ in routine

Received for publication 1 Oct. 2004. Accepted for publication 10 Feb. 2005. Contribution from Clemson Univ. Agricultural Experiment Station.

${ }^{1}$ Program associate.

${ }^{2}$ Associate professor. To whom reprint requests should be addressed; e-mail haibol@clemson.edu.

${ }^{3}$ Professor. creeping bentgrass management to minimize resistance caused by uneven shoot growth for longer and more consistent putting green ball roll.

Researchers have recently investigated effects of TE on creeping bentgrass putting green ball roll distances. 'Penncross' creeping bentgrass treated monthly with TE at $0.05 \mathrm{~kg} \cdot \mathrm{ha}^{-1}$ had increased ball roll distances relative to untreated turf (Fagerness et al., 2000). Despite diurnal leaf growth, TE treated bentgrass may still provide greater ball roll distances throughout a given day. Creeping bentgrass putting green ball roll distances were increased greater or equivalent to supplemental mowing operations on non-PGR treated turf following initial TE applications at $0.05 \mathrm{~kg} \cdot \mathrm{ha}^{-1}$ (McCullough et al., 2005b). Turf managers may be able to reduce putting green mowing frequencies without compromising ball roll distances following applications of TE.

Although TE is currently registered for periodic applications on creeping bentgrass putting greens, various application strategies may be applicable in promoting long-term ball roll distances. However, effects of incremental TE applications on seasonal bentgrass putting green ball roll have not been reported. Furthermore, the influence of TE on weekly ball roll distances for extended periods is limited for creeping bentgrass greens and warrants further investigations. The objective of this experiment was to investigate effects of three incremental TE application regimens, each totaling $0.2 \mathrm{~kg} \cdot \mathrm{ha}^{-1}$ over 12 weeks, on 'L-93' creeping bentgrass putting green ball roll distances.

\section{Materials and Methods}

Field experiments were conducted for twelve weeks at the Turfgrass Service Center, Clemson, S.C., from May to July 2003 and 2004 on an 'L-93' creeping bentgrass putting green established in August 2002. The green was constructed approximately to U.S. Golf Association (USGA) specifications (USGA Green Section Staff, 1993) and was Poa annua (L.) free. Soil medium consisted of $20 \%$ coarse sand ( 0.5 to $1.0 \mathrm{~mm}), 29 \%$ medium sand $(0.25$ to $0.5 \mathrm{~mm}), 30 \%$ fine sand $(0.1$ to $0.25 \mathrm{~mm})$, and $21 \%$ very fine sand $(<0.1$ $\mathrm{mm}$ ) with a $5.5 \mathrm{pH}$.

Turf was maintained at a $3.2 \mathrm{~mm}$ mowing height and irrigated as needed to prevent plant wilt. Aerifications were performed on the green 23 Sept. 2003 and 8 Mar. 2004 with 1.3-cm-diameter hollow tines. Beginning in March 2004, bentgrass was fertilized with N at $6 \mathrm{~kg} \cdot \mathrm{ha}^{-1}$ per week, with a greens-grade granular fertilizer (Anderson's, Maumee, Ohio; $18 \mathrm{~N}-1 \mathrm{P}-15 \mathrm{~K})$. During active spring, summer, and fall growth, bentgrass received preventative fungicide applications including chlorothalonil, azoxystrobin, fosetyl-al, and propiconazole to control dollar spot (Sclerotinia homoeocarpa F.T. Bennet), pythium (Pythium spp.), and brown patch (Rhizoctonia solani Kuhn).

The experimental design was a randomized complete block with three replications of $1.5 \times 2.1$-m plots. Trinexapac-ethyl, in emulsifiable concentration (1EC), was applied at $0,0.017 \mathrm{~kg} \cdot \mathrm{ha}^{-1}$ per week, $0.033 \mathrm{~kg} \cdot \mathrm{ha}^{-1}$ per 2 weeks, and $0.05 \mathrm{~kg} \cdot \mathrm{ha}^{-1}$ per 3 weeks with a $\mathrm{CO}_{2}$ sprayer at $700 \mathrm{~L} \cdot \mathrm{ha}^{-1}$ beginning 1 May 2003 and 4 May 2004.

Weekly ball roll distances were measured on twelve and eleven sampling dates in 2003 and 2004, respectively. Six ball roll measurements (three rolls in opposite directions) were made per plot with a $38 \mathrm{~cm}$ stimpmeter in the morning (900 to $1100 \mathrm{HR}$ ) and in the evening $(>1700 \mathrm{HR})$. Morning ball roll measurements were made about $2 \mathrm{~h}$ after mowing. The stimpmeter was raised off of the ground until gravity caused the golf ball to roll off the cleft located on the opposite end. Ball roll distances were obtained with tape measures running parallel with the plots. The six rolls were pooled per plot for data analyses. Turf injury following TE applications was evaluated visually on a percent scale basis, where $0=$ no injury, $1 \%$ to $15 \%=$ minor discoloration, $16 \%$ to $30 \%=$ moderate injury, $>30 \%=$ unacceptable injury, and $100 \%$ = completely dead turf. Data were subjected to an analysis of variance with SAS General Linear Model procedure (SAS Institute, Cary, N.C.). Mean separations were based on Fisher's LSD test at the 0.05 probability level. 
Table 1. Monthly weather data from field experiments in 2003 and 2004 for Clemson, S.C.

\begin{tabular}{|c|c|c|c|c|c|}
\hline \multirow[b]{2}{*}{ Year } & \multirow[b]{2}{*}{ Month } & \multicolumn{3}{|c|}{ Temp $\left({ }^{\circ} \mathrm{C}\right)$} & \multirow{2}{*}{$\begin{array}{c}\text { Total } \\
\text { rainfall } \\
(\mathrm{cm})\end{array}$} \\
\hline & & $\overline{\mathrm{Avg}}$ & Min & $\overline{\operatorname{Max}}$ & \\
\hline \multirow[t]{3}{*}{2003} & May & 20 & 15 & 25 & 19 \\
\hline & June & 23 & 18 & 29 & 19 \\
\hline & July & 25 & 20 & 30 & 28 \\
\hline \multirow[t]{3}{*}{2004} & May & 22 & 16 & 28 & 10 \\
\hline & June & 25 & 19 & 30 & 12 \\
\hline & July & 25 & 20 & 30 & 19 \\
\hline
\end{tabular}

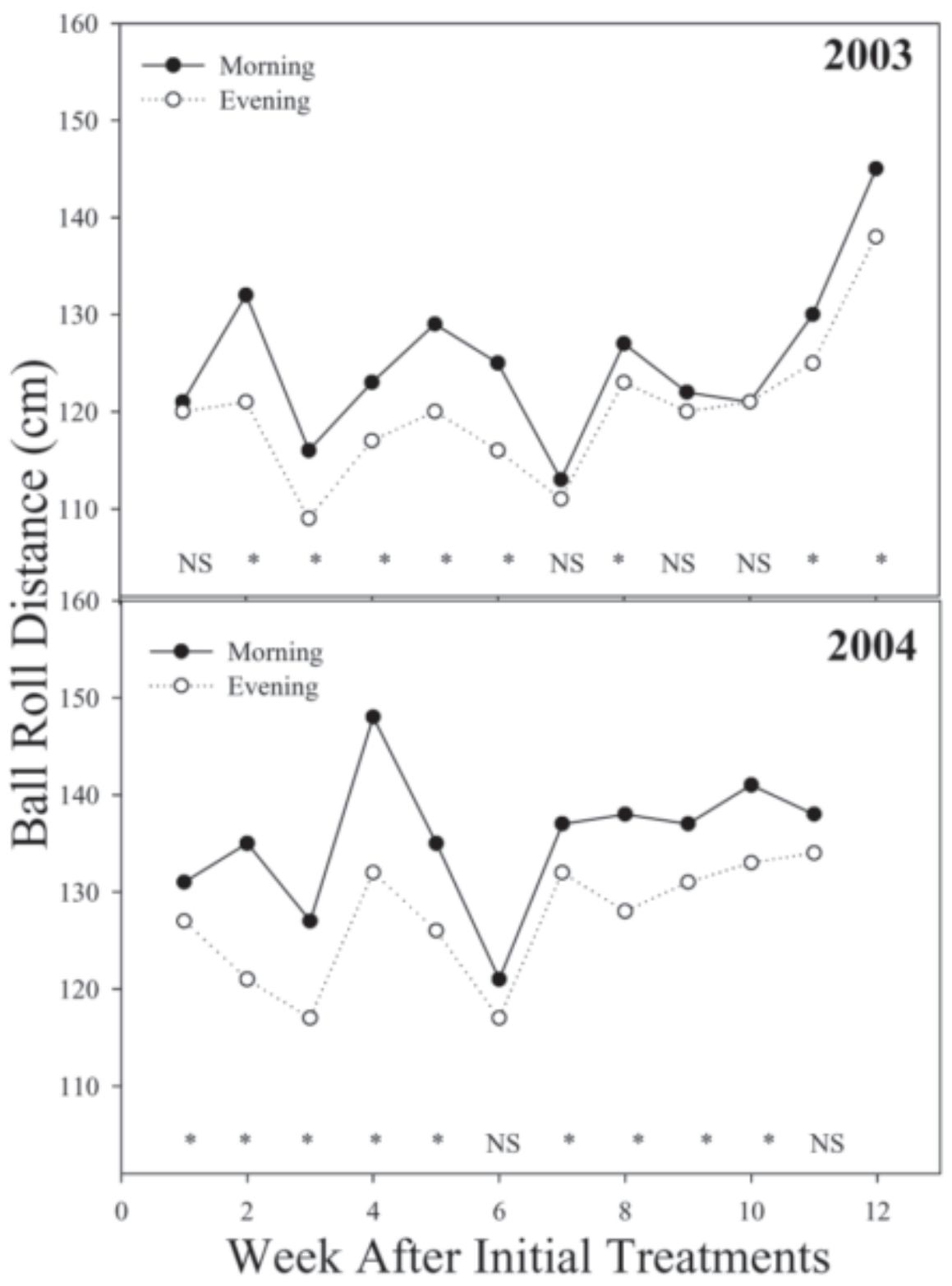

Fig. 1. Morning (9:00 to 11:00 HR) and evening (>17:00 HR) ball roll distances obtained with a $38 \mathrm{~cm}$ stimpmeter on an 'L-93' creeping bentgrass putting green in field experiments, May to July 2003 and 2004, Clemson, S.C. NS,"Nonsignificant or significant difference at the 0.05 probability level.

\section{Results and Discussion}

Year by time of day and year by TE regimen interactions were detected and thus results are presented separately by year. Over the test period, Clemson had higher daily temperatures in May and June in 2004 than in 2003 and total rainfall was about $10 \mathrm{~cm}$ greater per month in 2003 than 2004 (Table 1). Time of day by TE interactions were not detected suggesting TE effects were consistent from morning to evening despite diurnal differences observed in ball roll distances. Morning ball roll distances were significantly greater than evening on 8 dates in 2003 and 9 dates in 2004 (Fig. 1). Similar results were observed on creeping bentgrass and bermudagrass (Cynodon dactylon L. $\times$ C. transvaalensis) putting greens as diurnal leaf growth decreased evening ball roll distances relative to morning (Fagerness et al., 2000; McCullough, 2004; McCullough et al., 2005b).

Ball roll distances generally increased from June to late July 2003 and from early May to late July 2004 (Fig. 1). Creeping bentgrass likely had greater stress in 2004 due to higher temperatures and less rainfall, accounting for differences observed over the 2 years. Furthermore, progressive bentgrass leaf stress with increased temperatures from May to July may have resulted in longer ball roll distances. Turf injury did not occur following TE use regardless of application regimen (data not shown).

Ball roll distances were enhanced only from the $0.05 \mathrm{~kg} \cdot \mathrm{ha}^{-1}$ per 3 weeks TE regimen one week after initial treatments (WAIT) in both years (Fig. 2). In 2003, creeping bentgrass treated with TE generally had higher trends in ball roll distances from the untreated but enhancements were only significant on two, one, and two sampling dates from the weekly, biweekly, and triweekly TE regimens, respectively. In 2004, the weekly TE regimen enhanced ball roll distances on four sampling dates while biweekly and triweekly TE regimens only enhanced ball roll distances on two dates. Creeping bentgrass treated with biweekly and triweekly TE applications also had greater fluctuation in ball roll distances, compared to weekly TE regimens, likely from reduced efficacy before repeated applications. Results suggest frequent TE applications of low rates may produce more consistent bentgrass putting green ball roll than higher TE rates applied at greater time intervals. However, higher TE rates may be more appropriate for enhancing creeping bentgrass ball roll distances following initial applications.

Although TE improved ball roll distances without turf injury, significant enhancements were only temporary. Applying TE rates greater than 0.017 and $0.033 \mathrm{~kg} \cdot \mathrm{ha}^{-1}$ weekly and biweekly, respectively, may be more effective for consistently enhancing ball roll distances and warrants further investigations. Routine TE use at these intervals may be applicable when turf managers apply liquid fertilizations every 7 to $14 \mathrm{~d}$. Additionally, since disease pressure for creeping bentgrass increases during summer months, turf managers may also apply TE with routine fungicides at these intervals. Despite 'Penncross' and 'L-93' creeping bentgrasses having shown improved ball roll following TE applications, cultivars such as 'Crenshaw', 'Penn A', 'Penn G-2', and other bentgrass species may respond differently to TE treatments. Creeping bentgrass putting greens with Poa annua infestations may also have greater variability with ball roll following TE use and require future investigations.

\section{Literature Cited}

Fagerness, M.J., F.H. Yelverton, J. Isgrigg, and R.J. Cooper. 2000. Plant growth regulators and mowing height affect ball roll and quality of creeping bentgrass putting greens. HortScience 35:755-759.

Fagerness, M.J. and F.H Yelverton. 2001. Plant 


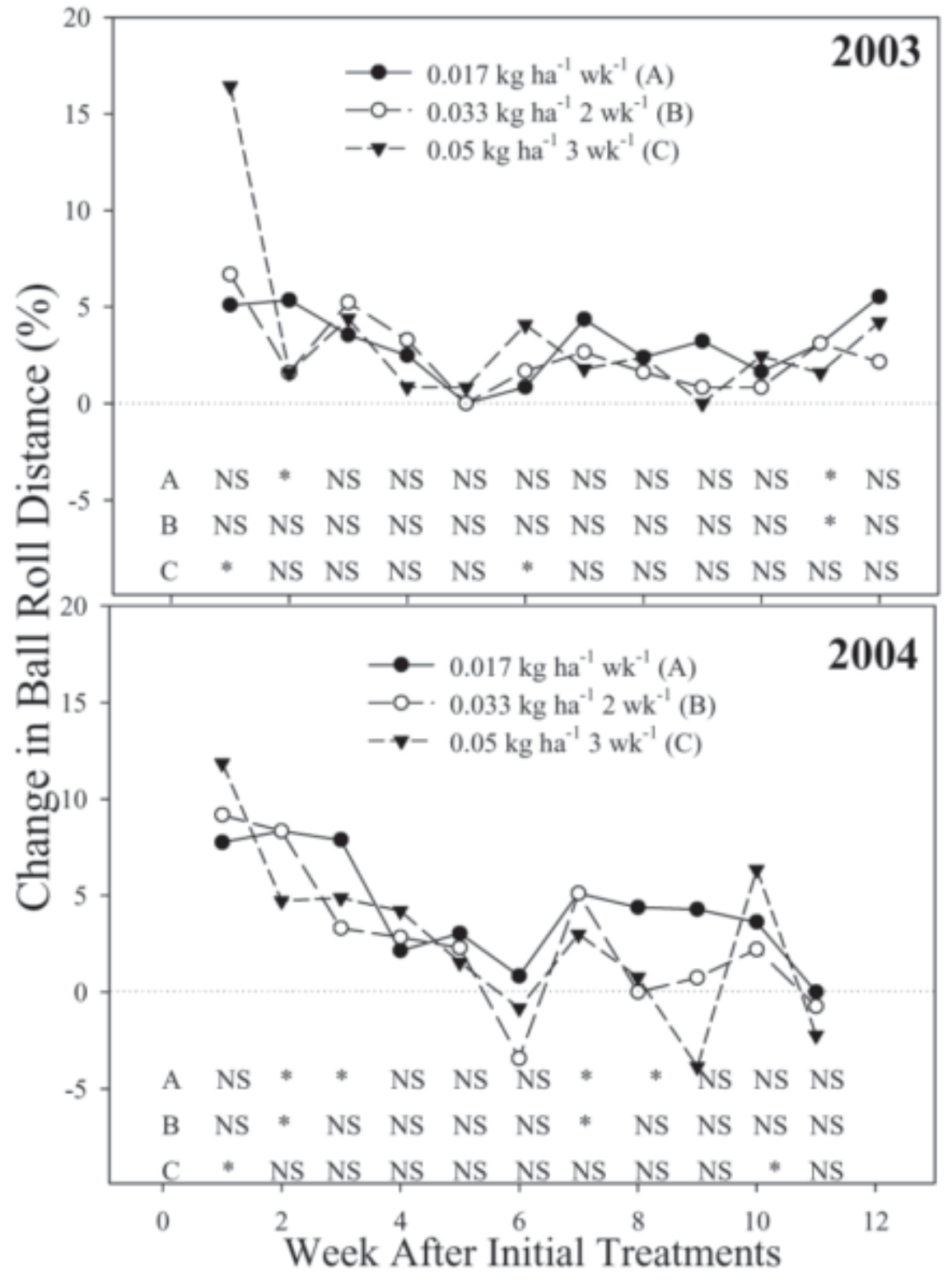

Fig. 2. Ball roll distances obtained with a $38 \mathrm{~cm}$ stimpmeter on an 'L-93' creeping bentgrass putting green treated with trinexapac-ethyl in field experiments, 2003 and 2004, Clemson, S.C. Results are presented as percent change relative to the untreated. ${ }^{N S, "}$ Nonsignificant or significant difference from 0 at the 0.05 probability level.

growth regulator and mowing height effects on seasonal root growth of Penncross creeping bentgrass. Crop Sci. 41:1901-1905.

Goss, R.M., J.H. Baird, S.L. Kelm, and R.M. Calhoun. 2002. Trinexapac-ethyl and nitrogen effects on creeping bentgrass grown under reduced light conditions. Crop Sci. 42:472-479.

McCarty, B. 2005. Management practices affecting putting speed, p. 457-464. In: L.B. McCarty (ed.). Best golfcourse management practices. 2nd ed. Prentice-Hall, Upper Saddle River, N.J.

McCullough, P.E. 2004. Physiological response of 'TifEagle' bermudagrass to nitrogen and trinexapac-ethyl, p. 62-63. MS thesis. Clemson Univ., Clemson, S.C.

McCullough, P.E., S.E. Hart, and D.W. Lycan. 2005a. Plant growth regulator regimens reduce Poa аппиа populations in creeping bentgrass. Online. Appl. Turfgrass Sci. doi:10.1094/ATS2005-0304-01-RS.

McCullough, P.E., H. Liu, and L.B. McCarty. 2005b. Mowing operations influencecreeping bentgrass putting green ball roll following plant growth regulator applications. HortScience 40:471-474.

Murphy, T.R., T. Whitwell, B. McCarty, and F.H. Yelverton. 2005. Turfgrass plant growth regulators, p. 705-714. In: L.B. McCarty (ed.). Best golf course management practices. 2nd ed. Prentice-Hall, Upper Saddle River, N.J.

SAS Institute. 1999. The SAS system for Windows. v. 8.2. SAS Inst., Cary, N.C.

U.S. Golf Association Green Section Staff. 1993. USGA recommendations for a method of putting green construction. 1993 rev. USGA Green Sect. Rec. 31(2):1-3. 